\title{
IMPLEMENTASI PENDIDIKAN KARAKTER MELALUI MEDIA FILM DALAM PEMBELAJARAN PENDIDIKAN AGAMA ISLAM DI SMP NEGERI 1 CEMPA KABUPATEN PINRANG
}

\author{
Ridwan \\ Email: ridwanhaer@gmail.com \\ Guru SMPN 1 Cempa Pinrang
}

\begin{abstract}
This paper is about the Implementation of Character Education through Film Media in Learning Islamic Education in SMP Negeri 1 Cempa, Pinrang Regency. The purpose of this study is to describe the planning, implementation, and impact of the implementation of character education through film media in the learning process of Islamic Education in SMP Negeri 1 Cempa, Pinrang Regency.

This research is a qualitative research with a naturalistic paradigm. The instruments used in this study are: observation guidelines, interview guidelines, and researchers as key instruments. The informants interviewed in this study were principals, deputy heads of curriculum, Islamic Education teachers, and students. The results showed that the planning of character education using the film Sunan Kalijaga in the learning process of Islamic Education was done by planning in the form of a Learning Implementation Plan (RPP) supervised by the school, reviewing the media, and reviewing learning material. The implementation of character education is done by integrating character values into the material of Islamic Education, especially related to moral material using the film Sunan Kalijaga that is applied using the inquiry method. The implementation of character education through film media in the learning of Islamic Education has an impact in improving the quality of learning that is more fun, motivating, inspiring, and meaningful. In addition, students are inspired to live up to character values such as caring, courtesy and honesty to be applied in daily interactions.
\end{abstract}

Keywords: Character Education, Islamic Education, Sunan Kalijaga Film

\begin{abstract}
ABSTRAK
Tesis ini membahastentang Implementasi Pendidikan Karakter Melalui Media Film dalam Pembelajaran Pendidikan Agama Islam di SMP Negeri 1 Cempa Kabupaten Pinrang. Tujuan penelitian ini untuk mendeskripsikan perencanaan, pelaksanaan, dan dampak pelaksanaan pendidikan karakter melalui media film dalam proses
\end{abstract}


pembelajaran Pendidikan Agama Islam di SMP Negeri 1 Cempa Kabupaten Pinrang.

Penelitian ini merupakan penelitian kualitatif dengan paradigma naturalistis. Instrumen yang digunakan dalam penelitian ini, yaitu: pedoman observasi, pedoman wawancara, dan peneliti sebagai instrumen kunci. Narasumber yang diwawancara dalam penelitian ini adalah kepala sekolah, wakil kepala bidang kurikulum, guru Pendidikan Agama Islam, dan peserta didik.

Hasil penelitian menunjukkan, bahwa perencanaan pendidikan karakter menggunakan film Sunan Kalijaga dalam proses pembelajaran Pendidikan Agama Islam dilakukan dengan membuat perencanaan dalam bentuk Rencana Pelaksanaan Pembelajaran (RPP) yang disupervisi oleh pihak sekolah, telaah media, dan telaah materi pembelajaran. Pelaksanaan pendidikan karakter dilakukan dengan mengintegrasikan nilai-nilai karakter ke dalam materi Pendidikan Agama Islam terutama berkaitan dengan materi akhlak dengan menggunakan film Sunan Kalijaga yang diterapkan menggunakan metode inkuiri. Pelaksanaan pendidikan karakter melalui media film dalam pembelajaran Pendidikan Agama Islam berdampak dalam meningkatkan kualitas pembelajaran yang lebih menyenangkan, memotivasi, inspiratif, dan bermakna. Selain itu, peserta didik terinspirasi untuk menghayati nilai-nilai karakter seperti kepedulian, sopan santun, dan kejujuran untuk diaplikasikan dalam pergaulan sehari-hari.

Kata Kunci: Pendidikan Karakter, Pendidikan Agama Islam, Film Sunan Kalijaga

\section{PENDAHULUAN}

\section{Latar Belakang}

Pendidikan karakter merupakan isu penting dalam dunia pendidikan yang dewasa ini banyak mendapat perhatian berbagai kalangan. Generasi muda mengalami krisis moralitas dan karakter yang luar biasa seiring dengan perkembangan dan kemajuan zaman. Pendidikan karakter menopang kehidupan berbangsa dan bernegara karena kemajuan bangsa tidak tergantung pada kualitas kognitif ansich, melainkan juga sangat ditentukan oleh kualitas afektif masyarakat. Dengan kata lain, bangsa yang maju tidak ditentukan oleh kecerdasan intelektual semata, tetapi juga sangat dipengaruhi oleh kecerdasan sikap spiritual maupun sikap sosial.Sejak jaman dahulu, masyarakat memandang institusi pendidikan tidak semata-mata untuk keperluan kecerdasan ilmu pengetahuan, melainkan difungsikan pula untuk mendidik generasi yang memiliki karakter, perilaku, dan budi pekerti yang baik dan mulia. 
Bagaimana mengintegrasikan nilai-nilai karakter ini dalam pembelajaran, sehingga melahirkan generasi muda yang memiliki kepribadian yang mulai, adalah tantangan dunia pendidikan saat ini. Maka diperlukan strategi yang efektif baik dalam proses penyampaian pesan-pesan moralitas yang menggugah peserta didik maupun strategi lain yang berkaitan dengan kebijakan pemerintah.

Diperlukan pula pemanfaatan media yang efektif dalam penyampaian informasi. Media berbasis teknologi informasi dapat dijadikan sebagai pilihan untuk menyampaikan pesan kepada peserta didik. Jika dulu pesan-pesan disampaikan dengan mengandalkan model ceramah dan hafalan, maka saat ini banyak fasilitas teknologi yang dapat dimanfaatkan untuk memediasi guru dalam menyampaikan informasi salah satunya adalah film.

Film atau gambar hidup merupakan gambar-gambar dalam frame di mana frame demi frame diproyeksikan melalui lensa proyektor secara mekanis, sehingga pada layar terlihat gambar itu hidup. Film bergerak dengan cepat dan bergantian, sehingga memberikan visual yang kontinu.

Salah satu film yang banyak memuat pendidikan nilai-nilai karakter dan telah diimplementasikan di SMP Negeri 1 Cempa adalah film Sunan Kalijaga. Beberapa potongan film Sunan Kalijaga pun telah digunakan dalam proses pembelajaran terutama dalam pembelajaran nilai-nilai akhlak yang sangat mendukung penanaman lima nilai pendidikan karakter yang telah disusun oleh kementerian pendidikan nasional, yaitu: religius, nasionalis, mandiri, gotong royong, dan integritas.

Cerita Sunan Kalijagamemuat beberapa nilai dan pelajaran yang sangat relevan dengan nilai-nilai karakter dan relevan dengan Pendidikan Agama Islam. Cerita-cerita Sunan Kalijaga itulah yang banyak ditransformasi ke dalam bentuk film yang menarik untuk dijadikan media dalam penyampaian pesan-pesan moralitas kepada peserta didik dalam proses pembelajaran Pendidikan Agama Islam.Maka peneliti mengangkat judul: "Implementasi Pendidikan Karakter Melalui Media Film dalam Pembelajaran Pendidikan Agama Islam di SMP Negeri 1 Cempa Kabupaten Pinrang”.

\section{Rumusan Masalah}

Berdasarkan uraian dan penjelasan pada bagian latar belakang dan fokus penelitian, maka dapat dirumuskan masalah penelitian ini sebagai berikut:

1. Bagaimana perencanaan pendidikan karakter melalui media film dalam pembelajaran Pendidikan Agama Islam di SMP Negeri 1 Cempa Kabupaten Pinrang? 
2. Bagaimana pelaksanaan pendidikan karakter melalui media film dalam pembelajaran Pendidikan Agama Islam di SMP Negeri 1 Cempa Kabupaten Pinrang?

3. Bagaimana dampak pendidikan karakter melalui media film dalam pembelajaran Pendidikan Agama Islam di SMP Negeri 1 Cempa Kabupaten Pinrang?

\section{Telaah Pustaka}

\section{Penelitian Relevan}

Tesis oleh Muhammad Irsad, mahasiswaProgram Pascasarjana UIN Sunan Kalijaga, Yogyakarta, 2015dengan berjudul "Nilai-nilai Pendidikan Islam dalam Pemikiran Sunan Kalijaga Serta Kontribusinya Terhadap Pengembangan Pendidikan Islam".

Tesis karya Dimas Indianto S., mahasiswa Program Pascasarjana UIN Sunan Kalijaga, Yogyakarta, 2015, berjudul "Pendidikan Karakter Menurut Sunan Kalijaga."

Tesis ditulis Lasinrang Dg. Matara, mahasiswa Program Pascasarjana UIN Alauddin Makassar, 2012, berjudul: "Pembentukan Akhlak Mulia Peserta Didik di MAN Tolitoli Sulawesi Tengah (Studi Tentang Kontribusi Pendidikan Formal)".

Tesis ditulis Umi Halimah dengan judul, "Upaya Meningkatkan Minat dan Hasil Belajar Siswa pada Mata Pelajaran PAI dengan Menggunakan Media Film Kartun Serial Upin dan Ipin di SD Derekan Kecamatan Pringapus Kabupaten Semarang Tahun 2011/ 2012."

Tesis ditulis Corawali, mahasiswa Program Pascasarjana Universitas Muhammadiyah Makassar, 2011, berjudul: "Pemanfaatan Media Film dalam Peningkatan Kemampuan Menulis Drama pada Kelas IX B SMP Negeri 2 Lembang Kabupaten Pinrang”.

\section{Landasan Teori}

\section{Konsep Pendidikan Karakter}

Pendidikan karakter secara historis sudah menjadi perhatian orang sejak zaman dahulu. Dengan demikian, konsep tentang karakter anak didik telah menjadi perbincangan lama. Pendidikan kemudian dipahami tidak hanya sebatas transfer of knowledge, tetapi juga diartikulasikan sebagai wahana untuk menanamkan dan menumbuhkan nilai-nilai kebaikan. 


\section{Nilai-nilai Pendidikan Karakter}

Perkembangan selanjutnya, Kementerian Pendidikan dan Kebudayaan merumuskan nilai-nilai karakter itu ke dalam lima nilai utama yang masuk dalam program Penguatan Pendidikan Karakter (PPK) yang harus diintegrasikan ke dalam proses pembelajaran di sekolah. Kelima nilai utama PPK itu adalah: (1) religius; (2) nasionalis; (3) mandiri; (4) gotong royong; dan (5) integritas.

\section{Peranan Film dalam Pendidikan}

Film sebagai salah media audiovisual memiliki efektifitas yang sangat tinggi dalam proses pembelajaran. Peranan film ini sejalan dengan teori modus belajar yang dikemukakan oleh Bruner dalam Arsyad, sebagaimana dikutip Zainiyati. Pengalaman belajar dapat terjadi dalam tiga proses, yaitu pengalaman langsung (enactive), pengalaman piktorial atau melalui gambar (iconic), dan pengalaman abstrak (symbolic).

\section{Pembelajaran Pendidikan Agama Islam}

Pendidikan Agama Islam memiliki tanggungjawab untuk membentuk karakter peserta didik yang baik guna menjadi pribadi yang religius dan memiliki karakter sosial yang bernafaskan nilai-nilai Islam. Dengan harapan, jika proses pembelajaran Pendidikan Agama Islam berjalan dengan baik, maka akan melahirkan suatu masyarakat yang tidak hanya maju dalam pengetahuan tetapi menjadi masyarakat yang beradab.

\section{Jenis dan Pendekatan Penelitian}

Penelitian ini merupakan penelitian deskriptif kualitatif. Penelitian kualitatif menggali data secara langsung di lapangan secara alamiah dengan melakukan berbagai pengamatan terhadap tingkah laku dan melakukan wawancara langsung kepada individu-individu yang relevan dengan tema penelitian.

\section{Paradigma Penelitian}

Penelitian ini relevan dengan naturalistik paradigmakhususnya pada paradigma konstruktivisme yang memandang realitas sebagai bentukan dari manusia itu sendiri. 


\section{Sumber Data}

Kata-kata dan tindakan dari individu yang menjadi subjek penelitian atau informan adalah sumber data utama dalam penelitian kualitatif. Sementara data lainnya bersifat data pendukung berupa dokumen tertulis, foto, dan video. ${ }^{1}$

\section{Instrumen Penelitian}

Peneliti menggunakan beberapa instrumen yang membantu dalam proses penggalian data, yaitu: (1) pedoman observasi dan (2) pedoman wawancara.

\section{Teknik Pengumpulan Data}

Penggalian data dilakukan dengan menggunakan beberapa teknik yang tepat dengan jenis penelitian kualitatif. Ada tiga teknik pengumpulan data yang digunakan dalam penelitian ini, yaitu: observasi, wawancara, dan dokumentasi.

\section{Teknik Pengolahan dan Analisis Data}

Salah satu model analisis data yang digunakan dalam penelitian ini adalah model Spradely.

\section{Teknik Pengujian dan Keabsahan Data}

Data temuan penelitian perlu diproses lebih cermat sehingga data temuan benar-benar tidak menyimpang dari kebenaran objek penelitian. Dilakukan teknik pengujian keabsahan data melalui teknik ketekunan keajegan pengamatan dan triangulasi.

\section{PEMBAHASAN}

\section{Perencanaan Pendidikan Karakter Melalui media Film dalam Pembelajaran} Pendidikan Agama Islam di SMP Negeri 1 Cempa Kabupaten Pinrang

Perencanaan pembelajaran yang disusun oleh guru dituangkan dalam desain dan langkah-langkah pembelajaran yang sistematis mulai dari tahap pendahuluan, kegiatan inti pembelajaran, dan penutup. Langkah-langkah ini dirumuskan secara detail melalui RPP berdasarkan kurikulum 2013.

Desain pembelajaran di dalam RPP dirancang berdasarkan metode pembelajaran yang dipilih oleh guru. Metode pembelajaran yang disarankan dalam implementasi kurikulum 2013 terdiri atas empat metode, yaitu: (1) metode inkuiri

\footnotetext{
${ }^{1}$ Lexy J Moleong, Metodologi Penelitian Kualitatif, h. 157.
} 
atau descoverylearning; (2) problem basedlearning; (3)projectbasedlearning; dan (4)metode saintifik. Pemilihan salah satu metode pembelajaran mengharuskan guru menerapkan sintak pembelajaran yang sesuai dengan metode tersebut. Namun, semua metode yang digunakan ini mengharuskan guru untuk mengarah pada pembelajaran aktif atau pembelajaran yang berpusat pada peserta didik.

\section{Pelaksanaan Pendidikan Karakter Melalui Media Film dalam Pembelajaran Pendidikan Agama Islam di SMP Negeri 1 Cempa Kabupaten Pinrang.}

Penguatan pendidikan karakter dalam lingkungan sekolah sangatlah penting dan mendesak dilakukan mengingat tantangan perubahan yang sangat dinamis. Peserta didik perlu dibekali oleh nilai-nilai karakter yang sesuai dengan nilai-nilai agama dan budaya yang dianut masyarakat. Tantangan perubahan zaman ini sangat terasa mengingat determinasi kemajuan teknologi informasi yang sangat masif mempengaruhi kehidupan masyarakat hingga ke tingkat bawah.

Pembelajaran Pendidikan Agama Islam dilaksanakan dengan metode yang aktif dan kreatif. Guru menyiapkan segala bahan, materi serta media yang akan digunakan dalam menyampaikan materi pembelajaran Pendidikan Agama Islam berkaitan dengan nilai-nilai akhlak, termasuk film Sunan Kalijaga.

\section{Dampak Pendidikan Karakter Melalui media Film dalam Pembelajaran Pendidikan Agama Islam di SMP Negeri 1 Cempa Kabupaten Pinrang.}

Peserta didik tidak hanya termotivasi dalam mengikuti proses pembelajaran Pendidikan Agama Islam karena menggunakan media yang menarik perhatian mereka, tetapi yang juga tak kalah pentingnya adalah model pembelajaran dengan film Sunan Kalijaga memberikan dorongan psikologis kepada peserta didik untuk menerapkan nilai-nilai karakter dalam kehidupan sehari-hari. Implikasi pembelajaran yang dilakukan di dalam kelas melalui penanaman nilai-nilai karakter melalui media film membuat peserta didik bersikap lebih baik di lingkungan sekolah maupun di rumah.

\section{SIMPULAN}

Berdasarkan hasil penelitian dan pembahasan yang telah dipaparkan sebelumnya tentang "Implementasi Pendidikan Karakter Melalui media Film dalam Pembelajaran Pendidikan Agama Islam di SMP Negeri 1 Cempa Kabupaten Pinrang", maka dapat disimpulkan beberapa hal sebagai berikut:

1. Perencanaan pendidikan karakter melalui media film dalam proses pembelajaran Pendidikan Agama Islam di SMP Negeri 1 Cempa dilakukan dengan beberapa tahap, yaitu: (1) melakukan perencanaan administratif setiap 
awal tahun pembelajaran dengan membuat Rencana Pelaksanaan Pembelajaran (RPP). Untuk memastikan perencanaan pembelajaran di SMP Negeri 1 Cempa berjalan sesuai dengan harapan, maka sekolah melaksanakan proses supervisi guru secara berkala setiap tiga bulan yang dilaksanakan oleh bidang kurikulum; (2) telaah materi pembelajaran Pendidikan Agama Islam yang sinergis dengan Penguatan Pendidikan Karakter (PPK); dan (3) telaah film Sunan Kalijaga yang dijadikan sebagai media dalam menyampaikan materi pembelajaran terkait, misalnya pembelajaran

2. Pelaksanaan pendidikan karakter di SMP Negeri 1 Cempa diintegrasikan ke dalam proses pembelajaran Pendidikan Agama Islam dengan menggunakan media pembelajaran melalui media film. Adapun film yang dipilih adalah film Sunan Kalijaga karena memuat konten pembelajaran nilai-nilai karakter yang digunakan untuk membahas atau untuk menjelaskan materi Pendidikan Agama Islam kepada peserta didik. Film Sunan Kalijaga ditelaah dan dipilah sesuai dengan materi yang diajarkan. Langkah-langkah pelaksanaan pembelajaran dilakukan berdasarkan metode yang sejalan dengan kurikulum 2013, salah satu metode yang digunakan adalah metode inkuiri dengan lima tahapan, yaitu: (1) stimulus berupa penayangan potongan film Sunan Kalijaga yang sesuai dengan materi yang sedang dipelajari peserta didik; (2) mengajukan pertanyaan dan hipotesis berdasarkan materi dan tayangan yang telah ditampilkan; (3) mengeksplorasi data; (4) merumuskan simpulan dan jawaban; dan (5) mengkomunikasikan hasil kesimpulan antar peserta didik.

3. Dampakpelaksanaan pendidikan karakter melalui media film Sunan Kalijaga dalam proses pembelajaran Pendidikan Agama Islam menjadikan peserta didik termotivasi, antusias, tidak jenuh, mudah memahami materi, pembelajaran PAI lebih kontekstual, inspiratif, dan bermakna. Isi film Sunan Kalijaga mengandung nilai-nilai karakter seperti sikap empati, jujur, tawaduk, adil, tolong-menolong, dan lain sebagainya menginspirasi peserta didik dalam proses pembelajaran. Peserta didik menghayati arti penting dari karakter dan perilaku yang ditunjukkan oleh Sunan Kalijaga sebagai nilai-nilai kehidupan yang mendasar yang perlu diaplikasikan dalam kehidupan sehari-hari. 


\section{DAFTAR PUSTAKA}

Anita, Dewi Evi. "Walisongo: Mengislamkan Tanah Jawa (Suatu Kajian Pustaka)." Wahana Akademika: Jurnal Studi Islam dan Sosial 1, no. 2 (2016): 243266.

Aziz, Donny Khoirul. "Akulturasi Islam dan Budaya Jawa.” fikrah, 2013. Baso, Ahmad. Pesantren Studies; Kosmopolitanisme Peradaban Kaum Santri di Masa Kolonial. Jakarta: Pustaka Afid, 2012.

Handayani, Muslih Aris. "Studi Peran Film dalam Dunia Pendidikan." Insania 11, no. 2 (2006): 176-186.

Hasan, Said Hamid. Pengembangan Pendidikan Budaya dan Karakter Bangsa. Jakarta: Kementerian Pendidikan Nasional, 2010.

Kasdi, Abdurrohman. "The Role of Walisongo in Developing the Islam Nusantara Civilization." Addin 11, no. 1 (2017): 1-26.

Kholid, AR Idham. "Wali Songo: Eksistensi Dan Perannya Dalam Islamisasi dan Implikasinya Terhadap Munculnya Tradisi-Tradisi di Tanah Jawa." JURNAL TAMADDUN 1, no. 1 (2016). http://moraref.or.id/record/view/44511.

Latifah. "Film as Media of Religious Dialogue: The Reception of Three Indonesian Contemporary Films." Dinika: Academic Journal of Islamic Studies 1, no. 3 (30 Desember 2016): 263. https://doi.org/10.22515/dinika.v1i3.87.

Lickona, Thomas. Mendidik untuk Membentuk Karakter. Diterjemahkan oleh Juma Abdu Wamaungo. Jakarta: Bumi Aksara, 2012.

Listyarti, Retno. Pendidikan Karakter dalam Metode Aktif, Kreatif, dan Inovatif. Jakarta: Erlangga, 2012.

Madjid, Abdul, dan Dian Andayani. Pendidikan Agama Islam Berbasis Kompetensi Konsep dan Implementasi Kurikulum 2004. Bandung: Remaja Rosda Karya, 2004.

Mas'udi. "Dakwah Nusantara (Kerangka Harmonis Dakwah Walisongo dalam

Diseminasi Ajaran Islam di Nusantara)." At-Tabsyir: Jurnal Komunikasi Penyiaran Islam 3, no. 2 (2015).

Mayer, Richard E. Multimedia Learning. USA: Cambridge Press, 2009.

Moleong, Lexy J. Metodologi Penelitian Kualitatif. Bandung: Remaja Rosda Karya, 2017.

Muhaemin. Pengembangan Kurikulum Pendidikan Agama Islam di Sekolah, Madrasah, dan Perguruan Tinggi. Jakarta: Rajawali Pers, 2012. 
Santosa, Santosa, dan Yudi Armansyah. "Principles of Tolerance Sunan Kalijaga and His Contribution on Islamization of Java." Kontekstualita 28, no. 1 (2013): 34-46.

Sasono, Eric. "'Muslim sosial' dan pembaharuan Islam dalam beberapa film Indonesia." Makalah Diskusi Komunitas Salihara, 2011.

Sutrisno, Budiono Hadi. Sejarah Walisongo. Yogyakarta: Graha Pustaka, 2007. Tafsir, Ahmad. Ilmu Pendidikan Islam dalam Prospektif Islam. Bandung: Remaja Rosda Karya, 2002.

Tajuddin, Yuliyatun. "Walisongo Dalam Strategi Komunikasi Dakwah." ADDIN 8, no. 2 (2015) 